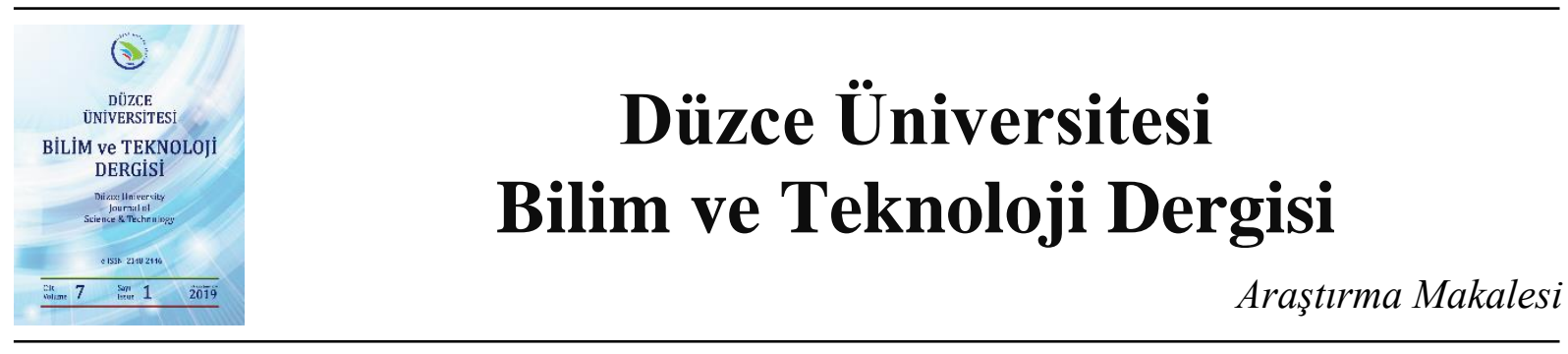

\section{Demiryolu Ulaştırma Türünün Türkiye Analizi; Dünyadaki Durumu, Sorunlar ve Beklentiler}

\author{
Hulusi AYDEMIR ${ }^{\text {a, }}$, M. Kürşat ÇUBUK ${ }^{\text {b }}$ \\ ${ }^{a}$ İnşaat Müh. B.(Müh. Fak.), Fen Bilimleri Enstitüsü, Gazi Üni. / TCDD Genel Müdürlüğ̈̈, Ankara, TÜRKİYE \\ ${ }^{b}$ Inşsaat Mühendisliği Bölümü, Mühendislik Fakültesi, Gazi Üniversitesi, Ankara, TÜRKiYE \\ * Sorumlu yazarin e-posta adresi: hulusiaydemir@tcdd.gov.tr
}

\begin{abstract}
ÖZET
Dünya ticaretinin artması ile birlikte günümüz dünyasında ulaştırma ağları ve sistemlerinin önemi artmış ve taşımacılık faaliyetlerinin artmasına yönelik çalışmalar güçlenmiştir. Dünyadaki konumu olsun bölgeler arasındaki geçişte olması sebebiyle olsun, birçok sebepten ulaştırma koridorlarında bulunan Türkiye'nin ulaştırma sistemleri oldukça önem arz etmektedir. Ulaştırma sistemlerinde dengesizliğin olduğu görülen ve verimli olmadığ gözlenen Türkiye'de, bu çalışma sonucu; ulaştırma sistemlerinde dengesizliği düzeltebilecek ve verimi artıracak olan sistemin demiryolları olduğu görülmektedir. Bunun içinde, Türkiye demiryollarının dünya ülkeleri ile karşılaştırılması ve analizi yapılmış, değerlendirilme yapılarak sorunlar ortaya koyulmuş ve beklentiler sunulmaya çalışılmıştır.
\end{abstract}

Anahtar Kelimeler: Demiryolları, Yük taşımacıllğ̆, Yolcu taşımacıllğ̆, Ulaştırma planlaması, Ulaştırma stratejileri

\section{Railway Transportation Mode Analysis on Turkey; the Situation in all around the World, Problems and Expectations}

\begin{abstract}
As increase of trade all around the World nowadays the importance of transportation network and systems also increase and this situation result in the increase of work due to transportation activities. The transportation systems of Turkey have a significant effect due to the location of the country on the earth also the condition that provides to be an important path among different regions. Turkey, in which an unbalanced and inefficient transportation system has been observed, as a result of this study in order to deal with such problems railway transportation system has been shown as a valid solution. To reach such results, the comparison and analysis between the railway systems of Turkey and World countries have been done, and with help of such evaluation the problems and expectations is shown in the conclusion..
\end{abstract}

Keywords: Railways, Freight transport, Passenger transport, Transportation planning, Transportation strategies 


\section{GiRiș}

$\mathrm{D}^{\mathrm{i}}$ ünya ticaretinin artması ile birlikte günümüz dünyasında ulaştırma ağları ve sistemlerinin önemi artmış ve taşımacılık faaliyetlerinin artmasına yönelik çalışmalar güçlenmiştir. Ülkeler ekonomileri için ulaştırmaya ve ulaştırmanın bağlı olduğu alt sektörlere önem vermekte ve dünya pazarından olabildiğince yüksek pay almak istemektedirler. Artan rekabet koşulları içinde bu payı artırmaya yönelik ülkeler yeni politikalar ve stratejiler belirlemektedir. Dünyadaki konumu olsun bölgeler arasındaki geçişte olması sebebiyle olsun, birçok sebepten ulaştırma koridorlarında bulunan Türkiye'nin ulaştırma sistemleri oldukça önem arz etmektedir. Türkiye'de ulaştırma sistemlerine baktığımızda karayolunun daha etkin ve yoğun olduğu görülmektedir. Karayolunun hakim olması, verimsiz ve dengesiz bir ulaştırma sisteminin oluşmasına neden olmuştur [1]. Bu çalışma sonucu, ulaştırma sistemlerinde dengesizliğin olduğu görülen ve verimli olmadığı gözlenen Türkiye'de, bu durumu düzeltebilecek ve verimi artıracak olan sistemin demiryolları olduğu görülmektedir. Sürdürülebilir bir ulaştırma sistemi planlaması ve stratejisi için ve karayollarının ekonomik büyümede tek başına yeterli olmadığı da düşünülürse demiryolları Türkiye için oldukça önemli olduğu görülmektedir.

Diğer taraftan ulaştırma sistemleri arasında dengesizliğin giderilmesinde de en önemli etkiye sahip ulaştırma sisteminin demiryolları olduğu düşünülürse; demiryollarının Türkiye açısından çok önemli olduğu açık ve net şekilde görülmektedir. Ancak, Türkiye'de 1950'li yıllardan sonra uygulanan karayolu ağırlıklı ulaşım politikaları sonucunda, 1950-1997 yılları arasında karayolu uzunluğu \%80 artarken, demiryolu uzunluğu sadece \%11 artmış olup, 1955 yılında genel ulaştırma sistemleri içerisinde yolcuda $\% 22$ ve yükte $\% 61$ olan demiryolunun pay1 1999 yılında, yolcuda $\% 2$ 'ye, yükte de $\% 5$ 'e düşmüştür [2, 3]. Geleceğin en önemli ulaştırma yöntemi olacağı öngörülen kombine taşımacılık da demiryolunun taşıma zincirine sokulabildiği ölçüde gelişebilecek, böylece dengeli ve sağlıklı bir ulaştırma sisteminin oluşması yönünde en doğru yola girilmiş olacaktır [4]. Bu sebeple Türkiye'de demiryolu yük taşımacılığının tüm ulaştırma türleri içerisindeki payının ve demiryolu yolcu taşımacılığı payının artması istendiği görülmektedir. Türkiye'de özellikle son yıllarda yapılan Yüksek Hızlı Demiryolu yatırımları ve işletme faaliyetleri artmıştır. Bugün yüksek hızlı trenler çok sayıda ülkenin, özellikle de kıta Avrupası, İngiltere, Japonya, Güney Kore ve Çin'in tercihi durumundadır. Bu ülkelerin çoğunda devlet desteği ile sürdürülen çalışmalar amaçlarına ulaşmaktadır. Uçaklarla boy ölçüşebilir bir hıza ve rahatlığa kavuşan yüksek hızlı trenler özellikle Batı Avrupa kara trafiğini hafifletmiş ve kara taşımacıllığı yüzünden her yıl bu ülkelerin gayri safi milli hâsılalarında meydana gelen kaybı azaltmıştır [5]. Tüm bunlara rağmen; Türkiye'de demiryollarının kullanımının gelişmiş ülkelere göre az olduğu ve bu ülkelerle rekabet düzeyini artırmak için demiryolu kullanımının artması için gerek altyapı gerekse yeni hatlar olmak üzere gerekli düzenleme ve çalışmalar yapılması gerekmektedir. Ayrıca Türkiye demiryolu ulaştırma sistemini ve ağını daha da geliştirerek dünyadaki diğer ülkeler ile arasında ulaştırma olanaklarını artırarak rekabet avantajı sağlamayı hedeflemeli ve değişen rekabet ortamına uyan yeni planlamalar ve stratejiler de belirlemelidir [6].

\section{TÜRKIYE’ DE DEMIRYOLU ULAȘTIRMA SISTEMININ DURUMU}

Türkiye'de 1923-1950 yılları arasında ortalama 3764 km demiryolu hattı yapıldığı ve işletmeye açıldığı, 1950 yılından sonra ise karayolu ağının gelişimi ile karayolu araçlarının artması sebebiyle, farklı ulaşım 
türlerinde dengeli büyüme olamamış ve bunun sonucunda 1950-2002 yıllarında sadece $945 \mathrm{~km}$ demiryolu hattı yapılabilmiştir [7].

2004-2013 yılları arasında da 1724 km yeni demiryolu hattı yapılmıştır [6]. Böylece 1950-2003 yılları arasında yılda ortalama $16 \mathrm{~km}$ olan yol yapımı, 2003-2011 y1lları arasında yılda ortalama 121 km' ye çıkmıştır [7]. Türkiye'nin yıllara göre taşımacılığının ulaştırma sistemlerine göre yüzdesel dağılımı Tablo 1'de gösterilmiştir [9-11].

Tablo 1. Türkiye'de taşımacılı̆̆ın ulaştırma sistemlerine göre yüzdesel dă̆ılımı (\%)

\begin{tabular}{|c|c|c|c|c|c|c|c|c|c|}
\hline \multirow[b]{2}{*}{ Yillar } & \multicolumn{5}{|c|}{$\begin{array}{c}\text { Yük } \\
(\text { Netton-Km) }\end{array}$} & \multicolumn{4}{|c|}{$\begin{array}{c}\text { Yolcu } \\
\text { (Yolcu-Km) }\end{array}$} \\
\hline & 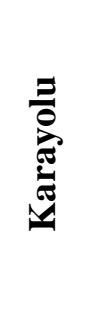 & 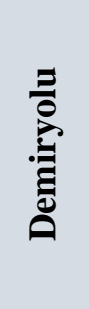 & 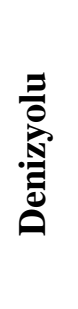 & 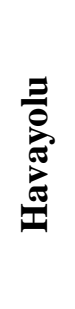 & 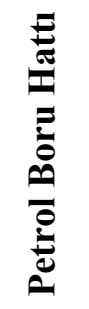 & 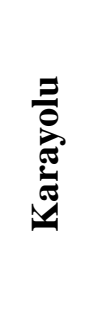 & 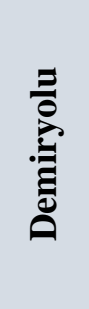 & 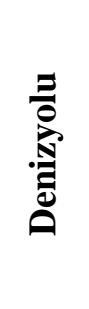 & 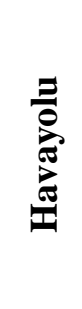 \\
\hline 1950 & 25,0 & 68,2 & 6,8 & 0 & 0 & 50.3 & 42.2 & 7.5 & 0 \\
\hline 1960 & 45.0 & 52.9 & 2.0 & 0.1 & 0 & 72.9 & 24.3 & 2.0 & 0.8 \\
\hline 1970 & 75.4 & 24.3 & 0.2 & 0.1 & 0 & 91.4 & 7.6 & 0.3 & 0.7 \\
\hline 2000 & 71.0 & 4.3 & 6.4 & 0.1 & 18.2 & 96.0 & 2.2 & 0,0 & 1,8 \\
\hline 2010 & 75,0 & 4,5 & 5,0 & $\ldots$ & 15,6 & 97,8 & 1,6 & 0,7 & $\ldots$ \\
\hline 2012 & 76,8 & 4,1 & 5,8 & $\ldots$ & 13,3 & 96,3 & 1,1 & 0,6 & 6,97 \\
\hline 2013 & 88,7 & 4,4 & 6,9 & $\ldots$ & $\ldots$ & 90,5 & 1,0 & 0,56 & 7,88 \\
\hline 2014 & 89,5 & 4,6 & 5,9 & $\ldots$ & $\ldots$ & 89,8 & 1,1 & 0,59 & 8,52 \\
\hline 2015 & 89,8 & 3,9 & 6,3 & $\ldots$ & $\ldots$ & 89,2 & 1,1 & 0,56 & 9,14 \\
\hline 2016 & 89,7 & 4,1 & 6,1 & $\ldots$ & $\ldots$ & 89,3 & 1,0 & 0,33 & 9,41 \\
\hline 2017 & 89,2 & 4,3 & 6,4 & $\ldots$ & $\ldots$ & 88,8 & 1,0 & 0,59 & 9,59 \\
\hline
\end{tabular}

Tablo 1'e göre; Türkiye'de 1950'li yıllarda demiryolu yük taşımacıllğının oranı \%68,2 iken, karayolunun payı ise \%25,0 olduğu görülmektedir. Bu oranların 2000 y1lında demiryolu için \%4,3'e gerilediği, karayolu için ise \%71,0'a yükseldiği görülmektedir. 2017 y1lına gelindiğinde ise demiryollarının yük taşımacılığında oranı \%4,1, karayollarının oranı ise $\% 89,2$ olmuştur. Yolcu taşımacılığında Tablo 1'e göre yine karayollarının üstünlüğü net bir şekilde görülmektedir. 1950'de karayollarının yolcu taşımacılığında oranı \%50,3 iken 2000 yılında \%96,0; 2010 yılında \%97,8 ve 2017 yılına gelindiğinde ise \% 88,8 olduğu görülmektedir. Diğer taraftan havayolu yolcu taşımacıllı̆gnın giderek arttı̆̆ görülmektedir. Örneğin 2012 yılında havayolu taşımacıllğının oranı \% 7,0 iken 2015 y1lında bu rakam \%9,1'e, 2017 yılında \%9,59'a yükselmiştir. Demiryollarının yolcu taşımacılığına bakıldığında ise 1950 yılında $\% 42,2$ olduğu, 2000 y1lında $\% 2,2 ; 2017$ yılına gelindiğinde ise $\% 1,0$ olduğu görülmektedir. Demiryollarının yüksek hızlı trenler yapılmasına karşın oransal olarak 
baktığımızda yolcu taşımacılık payında çok küçük bir paya sahip olduğu ve 1950 yılından itibaren genel olarak düşüş eğiliminde olduğu görülmektedir. Bu noktadan bakıldığında; 1950'den sonra dengeli bir ulaştırma politikası yürütülmediği bunun sebebiyle de gerek yük gerekse yolcu taşımacıllı̆ında demiryollarının payında düşüş görüldüğü ifade edilebilir.

Yol yenileme ve poz çalışmaları nedeniyle 2012 yılında 21, 2013 yılında ise 31 ayrı hat boyunca yollar belli ve bazı sürelerde veya tamamen işletime kapatılmıştır. Bu nedenlerden dolayı, taşımalar çoğunluklu olarak yurt içerisinde yapılmaya başlanılmıştır. Yurt içi ve uluslararası daha uzun mesafeli taşımalardansa, daha kısa mesafeli taşımaların yapılması zorunluluğu oluşmuştur. Bu sebepten dolayı ortalama taşıma mesafesi 2012 yılı için 455 km iken, 2013 yılına gelindiğinde 420 km'ye, 2015 yılı sonu itibari ile de 405 km'ye düşmüştür. Yaşanan olumsuzluklara rağmen; 2013 yılı içinde 26500000 ton-yük taşındığı ve 2003 yılına göre yük taşımacılık miktarı açısından \%67,0 oranında artış sağlandığ1 görülmektedir [8]. Ana hat yolcu taşımacıllı̆̆ için demiryollarının durumu düşünülürse; konvansiyonel hatlı trenlerde 2013 y1lı için, 2012 yılındaki duruma göre \%1,0, 2014 y1lında 2013 y1lına göre \%6,0, yüksek hızlı trenlerde ise $\% 26,0$ oranında artış sağlandığ 1 , uluslararası trenlerde ise $\% 21,0$ oranında azalma olduğu görülmüştür. Ana hat yolcu taşımacılığı açısından Toplamında ise, $\% 5,0$ oranında artış olmuştur [12]. 2015 yılı ana hat, YHT ve uluslararası toplam yolcu sayısı 23000000 'u aştığ 1,2017 yılında ise 27000000 ’u değerini geçtiği görülmektedir [10,11].

\section{III.TÜRKIYE’NIN DEMIRYOLLARI AÇISINDAN ANALIZİ; ULUSLARARASI KARȘILAȘTIRMALAR VE ÇIKARIMLAR}

\section{A. METODOLOJI VE YÖNTEM}

Öncelikli olarak Türkiye'nin demiryollarının yıllara göre durumu gösterilmiş ardından da dünyadaki çeşitli ve belirli ülkelerdeki durumları ile karşılaştırılma yapılarak analiz yapılmıştır. Bu karşılaştırmalarda demiryolu uzunluğu Tablo 2'de; ülkelerin nüfusları, demiryollarının yük ve yolcu taşıma paylarındaki oranları, miktarları ve ülkelerinin yüz ölçümü ile birlikte Tablo 3'de gösterilmiştir. Diğer taraftan ülkelerle karşılaştırma, değerlendirme ve analiz yapılırken net bir şekilde Türkiye'nin demiryollarının durumunun dünya ülkeleri içinde yerinin görülmesi ve diğer ülkelerin oransal olarak durumunun ortaya koyulması için Türkiye'nin mevcut durumu 1 kabul edilmiştir. Diğer ülkelerin Türkiye'nin değeri 1 olması durumunda alacağı değerler Tablo 5 ve Tablo 6'da gösterilmiştir. Son kısımda, Türkiye'nin demiryollarının durumuna dair genel çıkarımlar yapılarak, sorunlar ve beklentiler ifade edilmiştir.

\section{B. KARŞILAŞTIRMALAR ve BULGULARIN ORTAYA KONULMASI}

Dünyadaki bazı ülkelerin yıllara göre demiryolu uzunlukları Tablo 2'de gösterilmiştir [13]. 
Tablo 2. Ülkelerin yıllara göre demiryolu uzunluğu (km)

\begin{tabular}{|c|c|c|c|c|c|c|c|}
\hline Ülke İsmi & 2010 & 2011 & 2012 & 2013 & 2014 & 2015 & 2016 \\
\hline Arjantin & 25023 & 25023 & 25023 & 25023 & 25023 & 25325 & 25325 \\
\hline Belçika & 3578 & 3578 & 3575 & 3582 & 3631 & 3607 & 3602 \\
\hline Brezilya & 29817 & 29817 & 29817 & 29817 & 29817 & $\ldots$ & $\ldots$ \\
\hline Kanada & 58345 & 52002 & 52002 & 52002 & 52131 & $\ldots$ & 48498 \\
\hline İsviçre & 3543 & 3574 & 3551 & 3591 & 4018 & 3976 & $\ldots$ \\
\hline Çin & 66239 & 66050 & 66298 & 66585 & 66989 & 67212 & 67092 \\
\hline Almanya & 33708 & 33576 & 33509 & 33449 & 33426 & 33331 & 33380 \\
\hline İspanya & 15317 & 15680 & 15665 & 15582 & 15453 & 15711 & 15650 \\
\hline Finlandiya & 5919 & 5944 & 5944 & 5944 & 5944 & 5923 & 5926 \\
\hline Fransa & 33608 & 34621 & 30013 & 30013 & 30013 & 28987 & 28364 \\
\hline İngiltere & $\ldots$ & 16408 & 16423 & 15857 & 16530 & 16241 & $\ldots$ \\
\hline Endonezya & $\ldots$ & 4684 & 4684 & 4684 & 4684 & $\ldots$ & $\ldots$ \\
\hline İran & 6073 & 8368 & 8368 & 8593 & 8560 & 8560 & 8576 \\
\hline Hindistan & 63974 & 64460 & 64460 & 65436 & 65808 & 66030 & 66030 \\
\hline İtalya & 18011 & 17045 & 17060 & 16752 & 16723 & 16724 & 16788 \\
\hline Japonya & 20035 & 20140 & 20140 & 19436 & 16703 & 16704 & 15108 \\
\hline Kore & 3379 & 3637 & 3650 & 3650 & 3668 & 3944 & 4071 \\
\hline Meksika & 26704 & 26704 & 26704 & 26704 & 26704 & $\ldots$ & $\ldots$ \\
\hline Polonya & 19702 & 19725 & 19617 & 18959 & 18942 & 18510 & 18429 \\
\hline Rusya & 85292 & 85167 & 84249 & 85266 & 85266 & 85262 & 85375 \\
\hline Ukrayna & 21705 & 21665 & 21643 & 21626 & 21626 & 20975 & 21603 \\
\hline ABD & 228513 & 228218 & 228218 & 228218 & 228218 & $\ldots$ & $\ldots$ \\
\hline Güney Afrika & 22051 & 20500 & 20500 & 20500 & 20500 & $\ldots$ & $\ldots$ \\
\hline Kazakistan & 14202 & 14184 & 14319 & 14767 & 14767 & 14767 & 15530 \\
\hline Türkiye & 9594 & 9642 & 9642 & 9718 & 10087 & 10131 & 10131 \\
\hline
\end{tabular}

Tablo 2'ye baktığımızda; en uzun demiryolu uzunluğu Amerika Birleşik Devletleri'nin olup, bunu sırasıyla Rusya, Çin ve Hindistan izlemektedir. Türkiye'nin demiryolu uzunluğu 2010 yılında 9594 km iken, 2013 yılında 9718 km'ye, 2016 yılında ise 10131 km'ye çıktığı görülmektedir. Diğer taraftan; tüm ülkeler demiryolu uzunluğunu artırmaya çalıştığı görülmektedir. Türkiye'nin de demiryolu uzunluğunu yıllar itibariyle artırdığı görülmektedir. Demiryolları uzunluğunun 2014 yılına ait değerlere göre grafiksel gösterimi ise Şekil 1'de gösterilmiştir. 
Bazı AB ülkeleri, AB-28 ülkeleri, Dünya ve Türkiye'de demiryolu uzunluğu yüzölçümü, $1000 \mathrm{~km}^{2}$ ye düşen demiryolu uzunluğu ve 100000 nüfusa düşen karayolu uzunluğunun 2014 ve 2016 yıllarındaki değerleri Tablo 3'de verilmiştir [9-13].

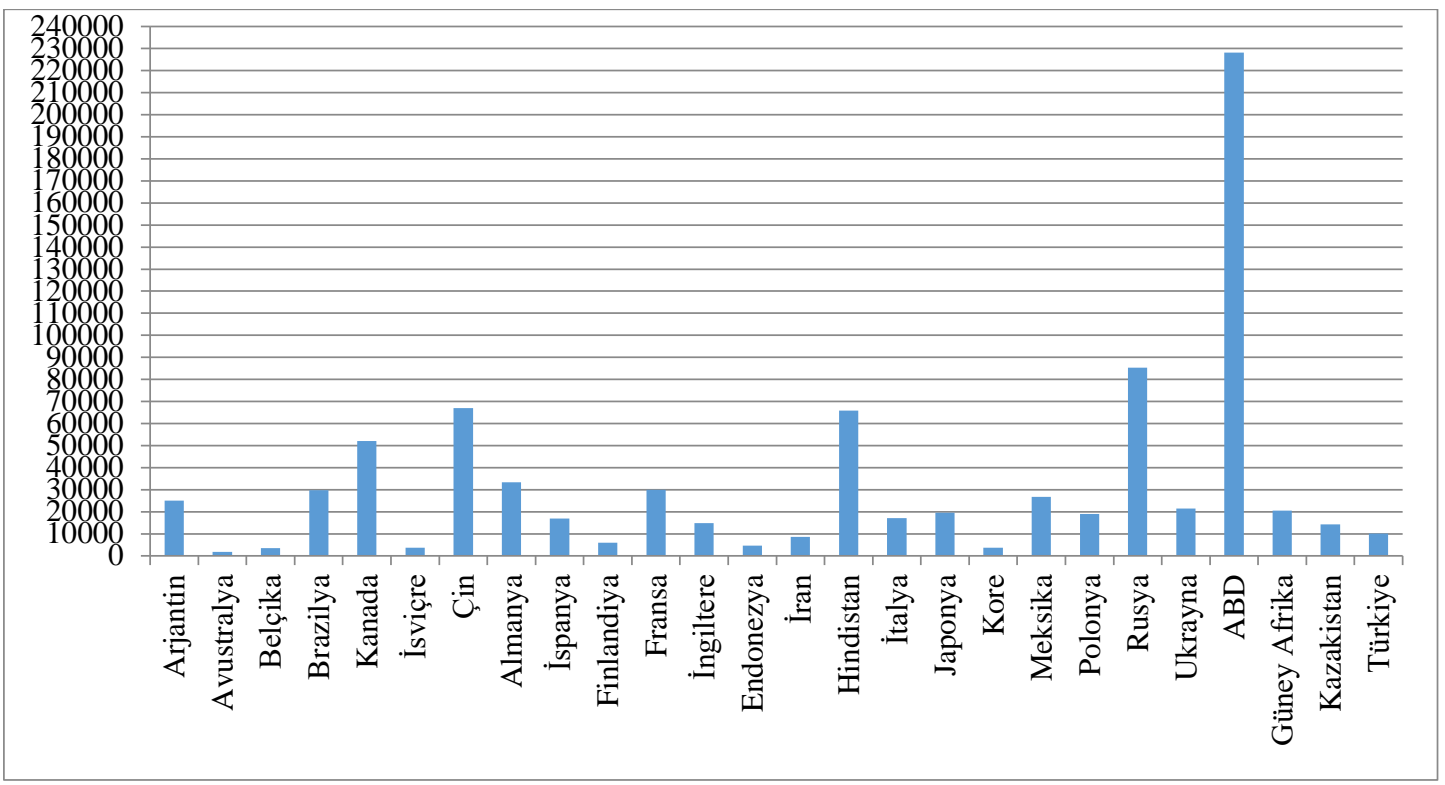

Şekil 1. 2014 yılı demiryolu uzunluklarının grafiksel gösterimi $(\mathrm{km})$

Tablo 3. Dünya ve Türkiye; nüfus, yüzölçümü değerlerine göre demiryollarının karşılaştırılması
ÜLKE
ÜLKE
YÜZ NÜFUS UZUNLUĞU
$(\mathrm{km})$
DEMIRYOLU
$1000 \mathrm{~km}^{2}$ 'ye
DÜŞEN
DEMIRYOLU
$(\mathrm{km})$
NÜFUSA
DÜŞEN
(1000 km²)
$\left(10^{6}\right)$
(km)
DEMIRYOLU
( $\mathrm{km})$

\begin{tabular}{cccccccccc}
\hline YIllar & & 2014 & 2016 & 2014 & 2016 & 2014 & 2016 & 2014 & 2016 \\
\hline TÜRKIYE & 785 & 76 & 79 & 10087 & 10131 & 13 & 13 & 13 & 13 \\
\hline ALMANYA & 357 & 82 & 82 & 33426 & 33380 & 94 & 94 & 41 & 41 \\
\hline FRANSA & 640 & 64 & 67 & 30013 & 28364 & 47 & 44 & 47 & 42 \\
\hline İNGILTERE & 243 & 64 & 66 & 15787 & 16241 & 65 & 67 & 23 & 25 \\
\hline $\begin{array}{c}\text { AB -28 } \\
\text { ULLELERI }\end{array}$ & 4511 & 505 & 510 & 224406 & 225652 & 50 & 50 & 44 & 44 \\
\hline ABD & 9629 & 320 & 323 & 228218 & 228218 & 24 & 24 & 71 & 71 \\
\hline ÇIN & 9561 & 1 & 1382 & 66989 & 67092 & 7 & 7 & 5 & 5 \\
\hline HINDISTAN & 3287 & 1252 & 1324 & 65808 & 66030 & 20 & 20 & 5 & 5 \\
\hline JAPONYA & 378 & 127 & 127 & 16703 & 15108 & 52 & 40 & 15 & 12 \\
\hline RUSYA & 17098 & 143 & 144 & 85266 & 85375 & 5 & 5 & 60 & 59 \\
\hline
\end{tabular}


Tablo 3'den de görüleceği üzere 2016 yılı için 100000 nüfusa göre düşen demiryolu uzunlukları Çin ve Hindistan için $5 \mathrm{~km}$, Japonya için $12 \mathrm{~km}$, Rusya için $59 \mathrm{~km}$, ABD için $71 \mathrm{~km}$, Almanya için $41 \mathrm{~km}$, Fransa için $42 \mathrm{~km}$, İngiltere için $25 \mathrm{~km}$ ve Türkiye için ise bu değer $13 \mathrm{~km}$ 'dir. Tablo 3'e göre 1000 $\mathrm{km}^{2}$ 'ye düşen $94 \mathrm{~km}$ demiryolu ile Almanya ilk sırada olup, 100000 nüfusa düşen demiryolunda ise Amerika Birleşik Devletleri $71 \mathrm{~km}$ ile ilk sıradadır. $1000 \mathrm{~km}^{2}$ 'ye düşen demiryolu değerinde ise AB28 ülkeleri için $50 \mathrm{~km}$ iken, Türkiye'de $13 \mathrm{~km}$ 'dir. 100000 nüfusa düşen demiryolu değerinde ise AB28 ülkelerinde $44 \mathrm{~km}$ ilen Türkiye'de 13 km olduğu görülmektedir.

Tablo 3'deki ülkelerden Türkiye'nin yüz ölçümü ve nüfus açısından en yakın ülke Fransa olduğu görülüyor. Fransa ile Türkiye'yi karşılaştırırsak; 1000 km² yüz ölçümüne düşen demiryolu değerinin Türkiye'den yaklaşık 3.6 kat daha fazla olduğu, 100000 nüfusa düşen demiryolu değerinde ise yaklaşık 3.2 kat daha fazla olduğu görülmektedir.

Şekil 2 ‘de $1000 \mathrm{~km}^{2}$ 'ye düşen demiryolu uzunluğu grafiksel olarak gösterilmiştir [9-13].

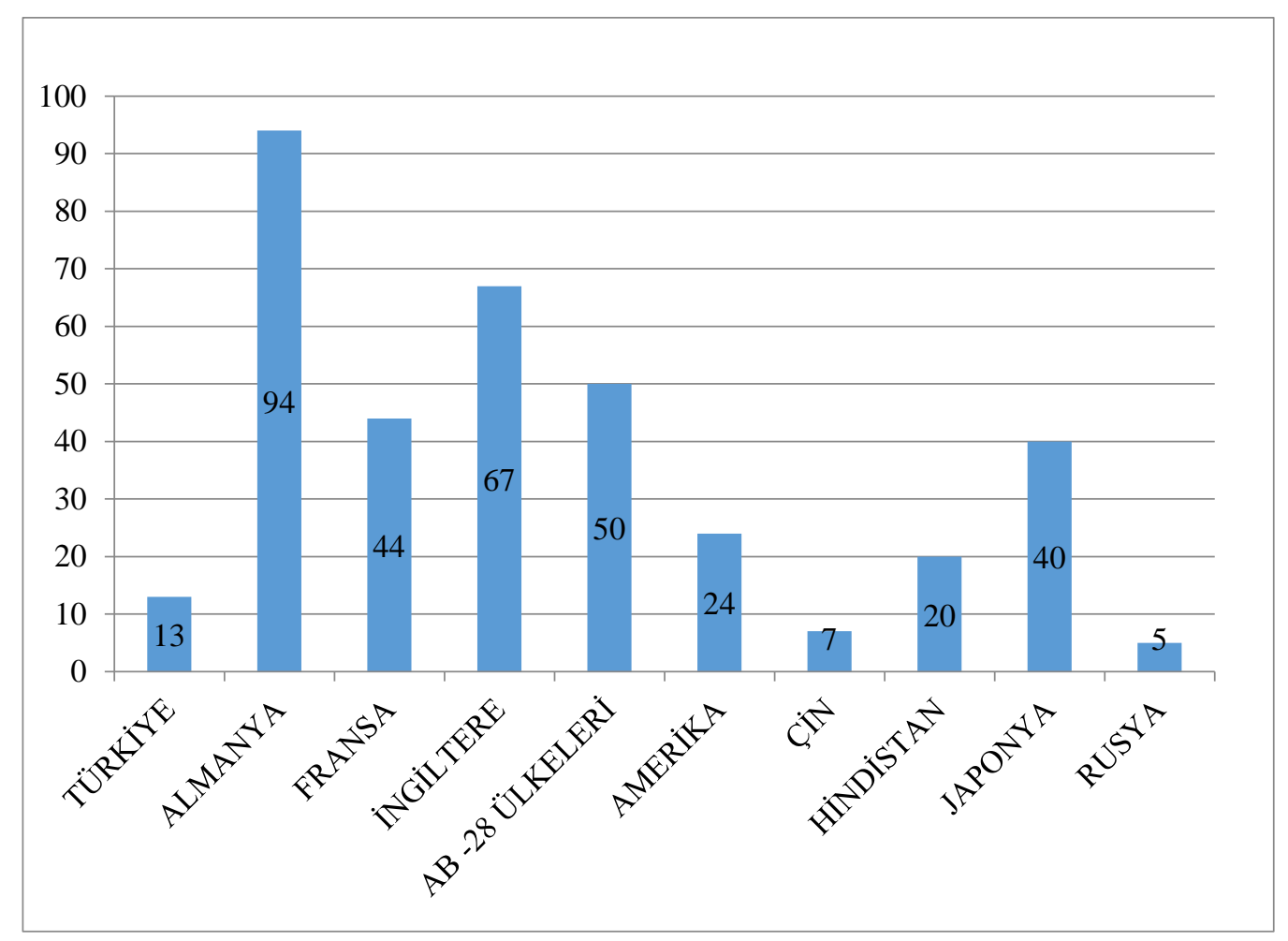

Şekil 2. Ülkelere göre $1000 \mathrm{~km}^{2}$ ye düşen demiryolu uzunluğu karşılaştırllması (km)

Şekil 2'den de görüleceği üzere Türkiye'nin birçok ülkeye göre $\mathrm{km}^{2}$ başına düşen demiryolu uzunluğunun az olduğu ve gerisinde kaldığı açık ve net olarak görülmektedir. Rusya ve Çin'e göre Türkiye için bu değerin fazla olmasının nedeni olarak ise söz konusu iki ülkenin yüz ölçümünün oldukça büyük olmasından kaynaklandığı ifade edilebilir.

Tablo 4' de Dünya ve Türkiye demiryolları ile yük taşımacılık değeri gösterilmiştir $[14,15]$. 
Tablo 4. Dünya ve Türkiye'de demiryolu ulaştırma sistemi ile yapılan yük taşımacılık değerleri (milyon ton-km)

\begin{tabular}{|c|c|c|c|}
\hline Ülke isimleri/Yıl & 2012 & 2013 & 2014 \\
\hline Arjantin & 12111 & 12111 & 12111 \\
\hline Avustralya & 21683 & 15143 & 15661 \\
\hline Belçika & 5439 & 5220 & 5439 \\
\hline Brezilya & 267700 & 267700 & 267700 \\
\hline Kanada & 352535 & 352535 & 352535 \\
\hline İsviçre & 8110 & 8585 & 9301 \\
\hline Çin & 2518310 & 2518310 & 2308669 \\
\hline Almanya & 105894 & 104259 & 74818 \\
\hline İspanya & 7507 & 7806 & 8005 \\
\hline Finlandiya & 9275 & 9470 & 9597 \\
\hline Fransa & 31616 & 31616 & 32012 \\
\hline Endonezya & 7166 & 7166 & 7166 \\
\hline İran & 22604 & 22604 & 24461 \\
\hline Hindistan & 625723 & 625723 & 665810 \\
\hline İtalya & 11249 & 10521 & 10322 \\
\hline Japonya & 20255 & 20255 & 20255 \\
\hline Kore & 9996 & 10459 & 10459 \\
\hline Meksika & 69185 & 69185 & 78770 \\
\hline Polonya & 32904 & 33256 & 32017 \\
\hline Rusya & 2222388 & 2222388 & 2298564 \\
\hline Ukrayna & 237722 & 237722 & 237722 \\
\hline ABD & 113342 & 113342 & 134600 \\
\hline Güney Afrika & 2524585 & 2524585 & 2524585 \\
\hline Kazakistan & 235846 & 235846 & 235845 \\
\hline Türkiye & 10691 & 10244 & 11145 \\
\hline
\end{tabular}


Tablo 4'e baktığımızda genelde tüm ülkelerin yük taşımacılık değerinin yıllar itibari ile arttığı görülmektedir. 2014 yılı için yük taşımacılığının değeri Türkiye için 11145000 ton-km olduğu, buna karşın ABD'de 134600000 ton-km, Brezilya'da 267700000 ton-km, Çin'de 2308669000 ton-km, Fransa'da 32012000 ton-km, İran'da 24461000 ton-km, Hindistan'da 665810000 ton-km, Japonya'da 20255000 ton-km, Rusya'da 2298564000 ton-km, Güney Afrika'da 2524585000 tonkm'dir. Buradan Türkiye'nin demiryollarında yük taşımacılığında dünya ülkeleri içinde oldukça geride kaldığı görülmektedir.

Şekil 3 ‘de 2014 yılı için bazı AB ülkeleri ile Türkiye'nin taşıdığı yükün grafiksel durumu gösterilmiştir $[10,11,14]$.

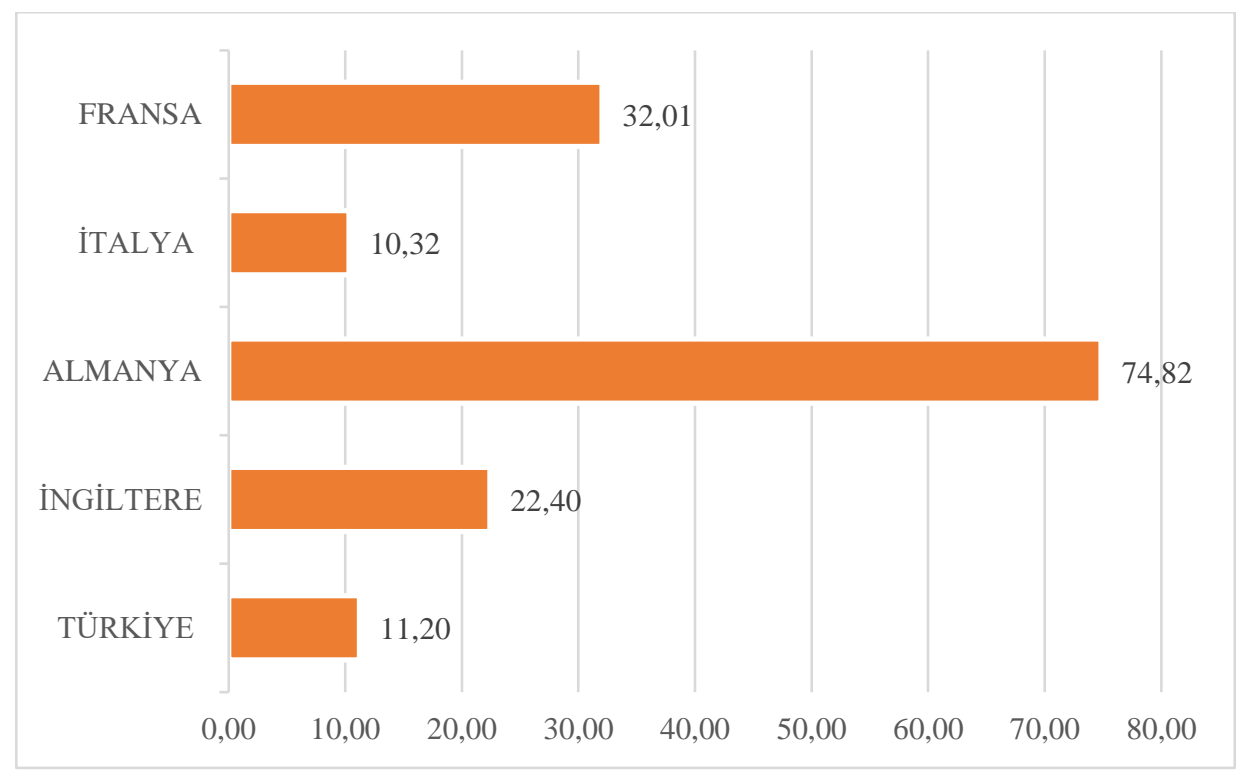

Şekil 3. Türkiye ve bazı AB ülkeleri için 2014 yllındaki yük taşıma değerlerinin grafikte gösterimi (milyar ton$\mathrm{km})$

Şekil 3'e göre Türkiye'de 11,20 milyar ton-km yük taşımacıllğ 1 yapılıyorken, Almanya'da 74,82 milyar ton-km; Fransa'da 32,01 milyar ton-km; İngiltere'de 22,40 milyar ton-km; İtalya'da ise 10,32 milyar ton-km olduğu görülmekte olup, Türkiye'nin; Almanya, İngiltere, Fransa'dan yük taşımacılığı olarak daha az değere sahip olduğu görülmektedir.

Tablo 5'de Türkiye'nin 2014 yılında taşıdığı yük değeri 1 kabul edildiğinde diğer ülkelerin aldığı değer gösterilmiştir.

Tablo 5'e baktığımızda; Rusya, Türkiye'den 206 kattan fazla, Çin 207 kat, Güney Afrika 226 kat, Brezilya 24 kat, Kazakistan 21 kat, ABD 12 kat, Meksika 7 kat, Japonya'da yaklaşık 2 kat fazla yük taşındığı görülmektedir. Tablodaki ülkelerden Belçika, İsviçre, Endonezya, İtalya, Güney Kore 'den ise Türkiye daha fazla yük taşıdığı için, bunların katsayıları 1'den daha küçük değer almıştır. 
Tablo 5. Dünya ülkelerinin 2014 yılı için yük taşımacılı̆̆ı açısından demiryolu ulaştırma sisteminde, Türkiye'den kaç kat fazla taşıdı̆̆ının gösterimi

\begin{tabular}{|c|c|c|}
\hline Ülke isimleri & 2014 & Ülke/Türkiye \\
\hline Arjantin & 12111 & 1,09 \\
\hline Avustralya & 15661 & 1,41 \\
\hline Belçika & 5439 & 0,49 \\
\hline Brezilya & 267700 & 24,02 \\
\hline Kanada & 352535 & 31,63 \\
\hline İsviçre & 9301 & 0,83 \\
\hline Çin & 2308669 & 207,15 \\
\hline Almanya & 74818 & 6,71 \\
\hline İspanya & 8005 & 0,72 \\
\hline Finlandiya & 9597 & 0,86 \\
\hline Fransa & 32012 & 2,87 \\
\hline Endonezya & 7166 & 0,64 \\
\hline İran & 24461 & 2,19 \\
\hline Hindistan & 665810 & 59.74 \\
\hline İtalya & 10322 & 0.93 \\
\hline Japonya & 20255 & 1.82 \\
\hline Güney Kore & 10459 & 0.94 \\
\hline Meksika & 78770 & 7.07 \\
\hline Polonya & 32017 & 2.87 \\
\hline Rusya & 2298564 & 206.24 \\
\hline Ukrayna & 237722 & 21.33 \\
\hline ABD & 134600 & 12.08 \\
\hline Güney Afrika & 2524585 & 226.52 \\
\hline Kazakistan & 235845 & 21.16 \\
\hline Türkiye & 11145 & 1.00 \\
\hline
\end{tabular}

Tablo 6 'da Türkiye ve dünya ülkelerindeki yolcu taşıma değerleri ve Türkiye'nin 2014 yılı değeri 1 olduğundaki durumu gösterilmiştir [13-15]. 
Tablo 6. Dünya ve Türkiye'nin demiryollarl yolcu taşıma değerleri(milyon yolcu-km) ve 2014 yll için Türkiye'nin yolcu taşıma değeri 1 olduğunda diğer ülkelerin durumu

\begin{tabular}{ccccc}
\hline Ülke İsmi & $\mathbf{2 0 1 2}$ & $\mathbf{2 0 1 3}$ & $\mathbf{2 0 1 4}$ & $\begin{array}{c}\text { Ülke/ Türkiye } \\
\text { (2014 yılı) }\end{array}$ \\
\hline Arjantin & 8588 & 8588 & 8588 & 1.95 \\
\hline Belçika & 10848 & 10848 & 10848 & 2.47 \\
\hline Çin & 795639 & 795639 & 807065 & 183.72 \\
\hline Almanya & 80210 & 79905 & 79340 & 18.06 \\
\hline Fransa & 85634 & 85634 & 83914 & 19.10 \\
\hline İngiltere & 64324 & 65928 & 65466 & 14.90 \\
\hline Endonezya & 20283 & 20283 & 20283 & 263.77 \\
\hline Hindistan & 978508 & 978508 & 1158742 & 9.06 \\
\hline İtalya & 38676 & 38938 & 39798 & 59.19 \\
\hline Japonya & 244591 & 244591 & 260014 & 29.32 \\
\hline Rusya & 144612 & 144612 & 128820 & 1.71 \\
\hline Tayland & 704 & 7504 & 7504 & 3.34 \\
\hline Güney Afrika & $\ldots$ & $\ldots$ & 14689 & 4393 \\
\hline Türkiye & 4598 & 3775 & & \\
\hline
\end{tabular}

Tablo 6'ya baktığımızda Türkiye'nin 2014 yılı için demiryolunda 4393000 yolcu-km değerine sahip olduğu, buna karşın Fransa'nın 83914000 yolcu-km, Almanya'nın 79340000 yolcu-km, Japonya'nın 260014000 yolcu-km olduğu görülmektedir. Ayrıca yine tablodan da görüleceği üzere, Rusya Türkiye'den 29 kat, Çin neredeyse 184 kat, Güney Afrika ortalama 3 kat, İngiltere 14.90 kat, Japonya 59 kat, Hindistan 263 kattan fazla yolcu taşımaktadır. Şekil 4'de ülkelerin 2014 yılı için değerlerinin grafiksel gösterimi bulunmaktadır. 


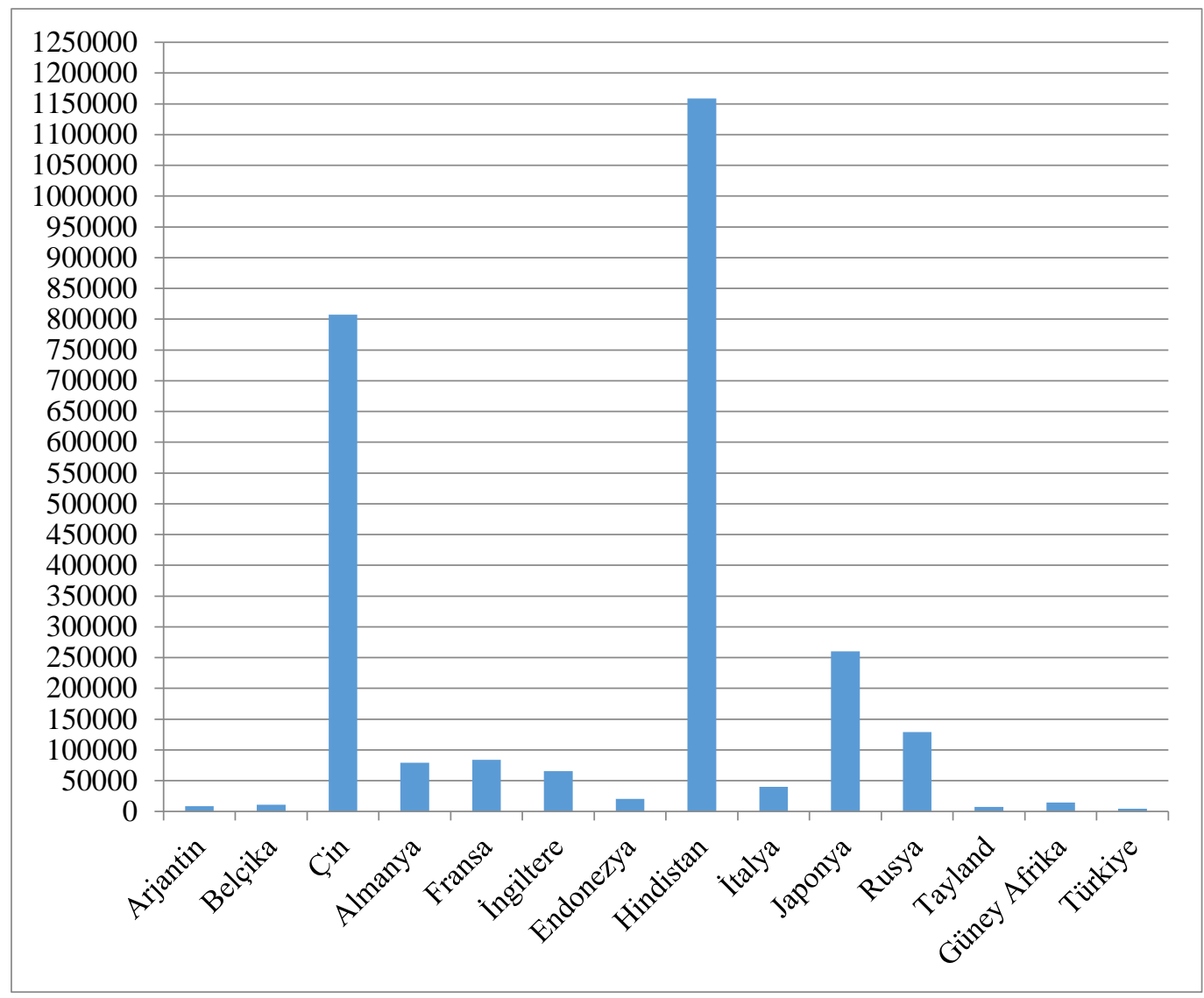

Şekil 4. Ülkelerin 2014 yılı için değerlerinin grafiksel gösterimi (milyon yolcu-km)

\section{SONUC}

Demiryollarının Türkiye'de yük taşımalarından aldığı payın ortalama \%4.0; yolcu taşımalarının payının ortalama \%1.5'nin altında olduğu, bunun sonucu olarak ulaştırma sistemlerinde verimliliğin azaldığı ve demiryolu ulaştırma sisteminin çok az kullanıldığg görülmektedir. Türkiye'de $\mathrm{km}^{2}$,ye düşen demiryolu uzunluğu ve mevcut demiryolları üzerindeki trafik yoğunluğu düşüktür. Demiryolu alt yapısının en önemli problemi büyük nüfuslu şehirlerarasındaki demiryolu hatlarının yüksek hız ve kaliteli servise uygun olmamasıdır. Son zamanlarda yapımına başlanılan ve artarak devam eden Yüksek Hızlı Demiryolu Hatları ile bu kapatılmaya çalışılsa da yeterli olmadığı ve yeni projelerin eklenmesi gerektiği görülmektedir. Türkiye'nin nüfusu ile aynı düzeyde bulunan ülkelerdeki demiryolu hat uzunluğunun daha fazla olduğu görülmektedir. Örneğin; İtalya'da 16788 km, İngiltere'de 16241 km, Fransa'da 28 $364 \mathrm{~km}$ demiryolu hattı bulunuyorken Türkiye' de bu değer $10131 \mathrm{~km}$ 'dir [11, 13]. Dünya ülkelerine baktığımızda ise Türkiye'nin daha da gerisinde olduğu net olarak görülmektedir. Örneğin; ABD'de 228 218 km, Çin'de 67092 km, Rusya'da 85375 km, Japonya'da ise $15108 \mathrm{~km}$ demiryolu hat uzunluğu bulunmaktadır [13].

Demiryollarıyla taşınan yük sayısı, Almanya'da Türkiye'nin yaklaşık 7 katı, Hollanda'da yaklaşık 3 kat1, ABD'de ortalama olarak 12 katı, Rusya'da ortalama olarak 206 katı, Çin'de ortalama 207 katı, Japonya'da ortalama 2 katıdır. Bu durumdan da anlaşılıyor ki, dünya ülkeleri içinde son yıllarda artan yük taşıma değerine rağmen yine az olduğu ve yeterli olmadığı gözükmektedir. Aynı şekilde, demiryollarıyla taşınan yolcu sayısı, Almanya'da Türkiye'nin yaklaşık 18 katı, Fransa'da yaklaşık 19 
katı, İngiltere'de ortalama olarak 15 katı, Rusya'da ortalama olarak 29 katı, Çin'de ortalama 183 katı, Japonya'da ortalama 59 katıdır. Son yıllarda artan yüksek hızlı tren yatırımlarının devam ederek artması ve bunu yeni planlar ve projeler eklenerek yolcu taşıma değerinin daha da artması sağlanılmalıdır.

$\mathrm{Bu}$ itibarla; demiryollarında gereken talebi karşılamaya yönelik yeni stratejilerin, planlamaların ve projelerin artarak devam etmesi, mevcut bulunan demiryolları hatlarının kalitesinin iyileştirilmesi, incelemeler sonucu mevcut hatlardan en verimli şekilde faydalanılarak modernize edilmesi gerekmektedir. Ayrıca, mevcut projelerin bitirilmesi yanında yeni projeler eklenerek gerek altyapı ve bakım gerekse yeni hatlar olmak üzere gerekli düzenleme ve çalışmalar yapılması gerektiği sonucuna ulaşılmaktadır.

\section{$\underline{\text { V. KAYNAKLAR }}$}

[1] H. Aydemir ve M. K Çubuk, 'Karayollarının Türkiye'de Genel Durumunun Araştırılması ile Yaşanan Değişimler ve Gelecek Stratejilerine Dair Tavsiyeler,' Gazi Mühendislik Bilimleri Dergisi (GMBD), vol. 2, no. 3, pp. 129-146, 2016.

[2] T.C. Devlet Demiryolları İşletmesi Genel Müdürlüğü, (2018, 2 Temmuz). Demiryollarının 161 yll . [Online]. Erişim: http://www.tcdd.gov.tr/content/e-kitap\#161.\%20YIL/18-19

[3] Ulaştırma ve Ulaşım Araçları Uyg-Ar Merkezi Araştırmacıları, "Ulaştırma ana planı stratejisi iii. rapor (sonuçlar ve öneriler)”, İstanbul Teknik Üniversitesi, Türkiye, 2005.

[4] S. Barda, Münakale Ekonomisi, İ.Ü. İktisat Fakültesi Yayını, İstanbul, Türkiye: Akgün Matbaas1, 1964.

[5] M. Karaşahin, "Türkiye demiryollarının mevcut durum analizi ve geleceği," II. Uluslararası Demiryolu Sempozyumu / Demiryolu Fuarı, İstanbul, Türkiye, 2008, ss. 33-43.

[6] H. Aydemir ve M. K Çubuk, 'Türkiye'nin Küresel Rekabet Gücü Açısından Türkiye Demiryollarının Değerlendirilmesi ve Türkiye'nin Demiryollarında Rekabet Etkisini Artırmaya Yönelik Öneriler,'’ Demiryolu Mühendisliği, s. 8, ss. 18-29, 2018.

[7] Anonim, '2011 yılı sektör raporu”, T.C. UDHB TCDD İşletmesi Genel Müdürlüğü, Türkiye, Rap. 8, 2011.

[8] Anonim, ”2013 y1lı sektör raporu”, T.C. UDHB TCDD İşletmesi Genel Müdürlüğü, Türkiye, Rap. 10, 18, 21, 40, 2013.

[9] T.C. Devlet Demiryolları İşletmesi Genel Müdürlüğü Araştırma Planlama ve Koordinasyon Dairesi Başkanlığı İstatistik Şubesi, T.C. Devlet Demiryolları istatistikylllı̆̆ 2011 - 2015, TCDD ISSN 1300-2503. Yayın No: 2016-2, Ankara, Türkiye: T.C. Devlet Demiryolları İşletmesi Genel Müdürlüğü, 2016, böl. 1-3, 9-11, ss.1-39, 101-114. 
[10] T.C. Devlet Demiryolları İşletmesi Genel Müdürlüğü Strateji Geliştirme Dairesi Başkanlığı İstatistik ve Analiz Şubesi, T.C. Devlet Demiryolları istatistik yıllı̆̆ 2012 - 2016, TCDD Yayın No: 2017-1, Ankara, Türkiye: T.C. Devlet Demiryolları İşletmesi Genel Müdürlüğü, 2017, ss. 61-68, 101108.

[11] T.C. Devlet Demiryolları İşletmesi Genel Müdürlüğü Strateji Geliştirme Dairesi Başkanlığı İstatistik ve Analiz Şubesi, T.C. Devlet Demiryolları istatistik yıllığı 2013 - 2017, TCDD Ankara, Türkiye: T.C. Devlet Demiryolları İşletmesi Genel Müdürlügü̈, 2018, ss., 88-91. 94-103.

[12] Anonim, "2012 yılı sektör raporu”, T.C. UDHB TCDD İşletmesi Genel Müdürlügü̈, Türkiye, Rap. 30, 2012.

[13] Anonim, (2018, 25 Kasım). Rail lines (total route- $\mathrm{km}$ ). The World Bank. [Online]. Erişim: http://data.worldbank.org/indicator/IS.RRS.TOTL.KM/countries?display=default

[14] Anonim, (2018, 25 Kasim). Railways, goods transported (million ton-km). The World Bank. [Online]. Erişim: http://data.worldbank.org/indicator/IS.RRS.GOOD.MT.K6

[15] Anonim, (2018, 25 Kasım). Railways, passengers carried (million passenger- $k m$ ). The World Bank. [Online]. Erişim: http://data.worldbank.org/indicator/IS.RRS.PASG.KM 